\title{
Case study of low-temperature heating in an existing single-family house-A test of methods for simulation of heating system temperatures
}

\author{
Østergaard, Dorte Skaarup; Svendsen, Svend
}

Published in:

Energy and Buildings

Link to article, DOI:

10.1016/j.enbuild.2016.05.042

Publication date:

2016

Document Version

Peer reviewed version

Link back to DTU Orbit

Citation (APA):

Østergaard, D. S., \& Svendsen, S. (2016). Case study of low-temperature heating in an existing single-family house-A test of methods for simulation of heating system temperatures. Energy and Buildings, 126, 535-544. https://doi.org/10.1016/j.enbuild.2016.05.042

\section{General rights}

Copyright and moral rights for the publications made accessible in the public portal are retained by the authors and/or other copyright owners and it is a condition of accessing publications that users recognise and abide by the legal requirements associated with these rights.

- Users may download and print one copy of any publication from the public portal for the purpose of private study or research.

- You may not further distribute the material or use it for any profit-making activity or commercial gain

- You may freely distribute the URL identifying the publication in the public portal 


\title{
Case study of low-temperature heating in an existing single-family house - a test of methods for simulation of heating system temperatures
}

Dorte Skaarup Østergaard*, Svend Svendsen

*Corresponding author. Tel. +45 422518 80, E-mail address: dskla@byg.dtu.dk.

Section of Building Energy, Department of Civil Engineering, Technical University of Denmark (DTU), Brovej, Building 118, 2800 Kgs. Lyngby, Denmark.

\begin{abstract}
:
Low-temperature heating provides an efficient way of heating our buildings. To obtain a high efficiency it is important that the heating systems in the buildings are operated with both low supply and return temperatures. This study set out to investigate how typical assumptions in the modelling of heat emissions from existing hydraulic radiators affects the heating system return temperatures calculated in a building simulation model. An existing single family house with hydraulic radiators was modelled in the simulation program IDA-ICE. Simulations were performed with various levels of detail and the calculated indoor temperatures and radiator return temperatures were compared to temperatures measured in the case house. The results showed that the detail of the simulation model has a large influence on the results obtained. The estimated return temperatures from the radiators varied by up to $16{ }^{\circ} \mathrm{C}$ depending on the assumptions made in the simulation model. The results indicated that a detailed building simulation model can provide a good estimate of the actual heating system operation, provided that actual radiators and realistic indoor temperatures are taken into account in the model.
\end{abstract}

KEYWORDS: low-temperature heating, radiator system, IDA-ICE, radiator exponent, design heating power, return temperature 


\section{Nomenclature:}

$T_{s}$

$T_{r}$

$T_{i}$

$P$

$q_{m}$

$C_{\text {water }}$

K

I

$n$

$\Phi_{0}$

$\Phi$

$\Delta T_{0}$

$\Delta T$

$\Delta T_{\text {arit }}$

$\Delta T_{\log }$

supply temperature

return temperature

indoor temperature

heat flux emitted from the water [W]

water mass flow rate $[\mathrm{kg} / \mathrm{s}]$

specific heat of water $\left[\mathrm{J} / \mathrm{kg}^{\circ} \mathrm{C}\right]$

power law coefficient depending on radiator height and width $\left[\mathrm{W} / \mathrm{m}{ }^{\circ} \mathrm{C}\right]$

length of the radiator [m]

radiator exponent [-]

design heating power at the standard test conditions [W]

heating power at the operating temperatures [W]

mean temperature difference between radiator and surroundings in the standard test

conditions $\left[{ }^{\circ} \mathrm{C}\right]$

mean temperature difference between radiator and surroundings at the operating

temperatures $\left[{ }^{\circ} \mathrm{C}\right]$

arithmetic mean temperature difference

logarithmic mean temperature difference 


\section{Introduction}

More than $25 \%$ of the final energy consumption in the EU is attributed to households [1]. The households are thereby the sector with the second largest final energy consumption in the EU, which makes the sector a central focus area for energy consumption reductions. One way of reducing the energy consumption of households in cold climates is to improve the efficiency of the heating systems. Low-temperature heating provides one promising solution to how this may be done. By reducing the heating system temperatures it is possible to increase the efficiency of heat production from solar collectors, heat pumps, and condensing boilers. Furthermore the heat loss from the distribution systems inside both new and existing buildings is reduced [2,3]. The highest heating system efficiencies are obtained when both supply and return temperatures are as low as possible. Recent research has therefore described the benefits of using heating system supply and return temperatures as low as $50^{\circ} \mathrm{C} / 20^{\circ} \mathrm{C}$ [4]. However while the supply temperature is often controlled according to a weather compensation curve, the return temperature is highly dependent on the design and operation of the heating system. This study therefore set out to test methods for evaluation of the possibility to obtain a low return temperature in heating systems with supply temperatures of $55^{\circ} \mathrm{C}$ or lower.

Recent studies have shown how new houses can be designed with a low-temperature heating system supplied by either low-temperature district heating [5], a heat pump [6], or a boiler [2]. Less focus has been put on the heating systems in existing houses. This is despite the fact that the existing buildings form the larger part of the building mass. In Denmark most existing houses are heated by hydraulic radiator systems that were dimensioned according to design temperatures such as $90^{\circ} \mathrm{C} / 70^{\circ} \mathrm{C}$ or $70^{\circ} \mathrm{C} / 40^{\circ} \mathrm{C}$. If these houses are to be heated by supply and return temperatures of $55^{\circ} \mathrm{C} / 25^{\circ} \mathrm{C}$ or lower, it may be necessary to evaluate whether the heating system is suited for this type of low-temperature operation. A reduction of the heating system supply temperature might lead to poor thermal comfort and high heating system return temperatures in case the existing radiators in the houses are too small. This could in turn lead to poor heating system efficiency. 
Recent studies that have investigated the use of radiator systems for low-temperature heating in existing buildings include [7], [8], [9], [10] and [11]. These studies investigated the heat supply and heat demand in certain case study buildings by applying numerical analysis $[9,10]$ or by using building simulation programs $[7-9,11]$. These types of analysis require that assumptions are made about the design heating power of current radiators and about the applicability of parameters and equations describing heat emissions from the radiators. For example, the estimation of the design heating power of the current radiators in the building investigated might be based on calculations of the design heat loss of the building and the design heating system temperatures $[7,8,10,11]$. Heat emissions from the radiators might be calculated using either arithmetic or logarithmic mean temperature differences, and by applying specified or standard radiator exponents. Another major assumption is that indoor temperatures can be based on standard setpoints of $20^{\circ} \mathrm{C}$ or $22^{\circ} \mathrm{C}[7,8,10]$.

Very little is known about the consequences of applying these assumptions. Therefore it is difficult to make reasonable assumptions and take into account any inaccuracies that might derive from such assumptions. This is important because the existing radiator sizes, may not correspond to the radiator sizes expected from the estimated design heat loss of the buildings [12]. Nor is it fully accurate to calculate the heat emission from the existing radiators using standard parameters and equations that have not been adjusted to the properties of low-temperature heating [13]. Lastly, indoor temperatures have a large effect on the heat emissions of a low-temperature heating system. Therefore accurate indoor temperatures may play a significant role for the validity of the results.

\subsection{Objective}

This paper set out to investigate the significance of the assumptions applied in simulations dealing with low-temperature radiator heating. The results from the study provide new knowledge on how dynamic simulations and measurements can be performed in order to obtain realistic results from evaluations of 
low-temperature heating systems - knowledge which may increase the accuracy of future studies in this area of research.

\section{Method}

The investigations presented in this paper were based on a case study of a Danish single-family house. The house was modelled in the commercial simulation tool IDA ICE and a number of simulations were performed to test how different assumptions affected the simulation results. The simulation results were evaluated with regard to indoor temperatures and heating system supply and return temperatures, and the calculated values were compared to temperatures measured in the house. The pros and cons of the investigated methods for simulation of low-temperature heating in existing buildings were discussed, and a suggestion was given for how to perform future studies on this topic.

\section{Case study \& simulation model}

The case study was based on a typical Danish red-brick house from the 1950s. The original part of the house consists of approximately $100 \mathrm{~m}^{2}$ of living area and a $70 \mathrm{~m}^{2}$ basement (of which $18 \mathrm{~m}^{2}$ is currently heated). In 1992, a two-storey extension was added to the house with $43 \mathrm{~m}^{2}$ on the ground floor and $27 \mathrm{~m}^{2}$ on the first floor. The house was modelled in the building simulation tool IDA ICE. The building construction was studied during a visit to the house and otherwise determined on the basis of drawing material and standard constructions at the time the house was built [14]. A picture of the case study house and the simulation model are shown in Figure 1.
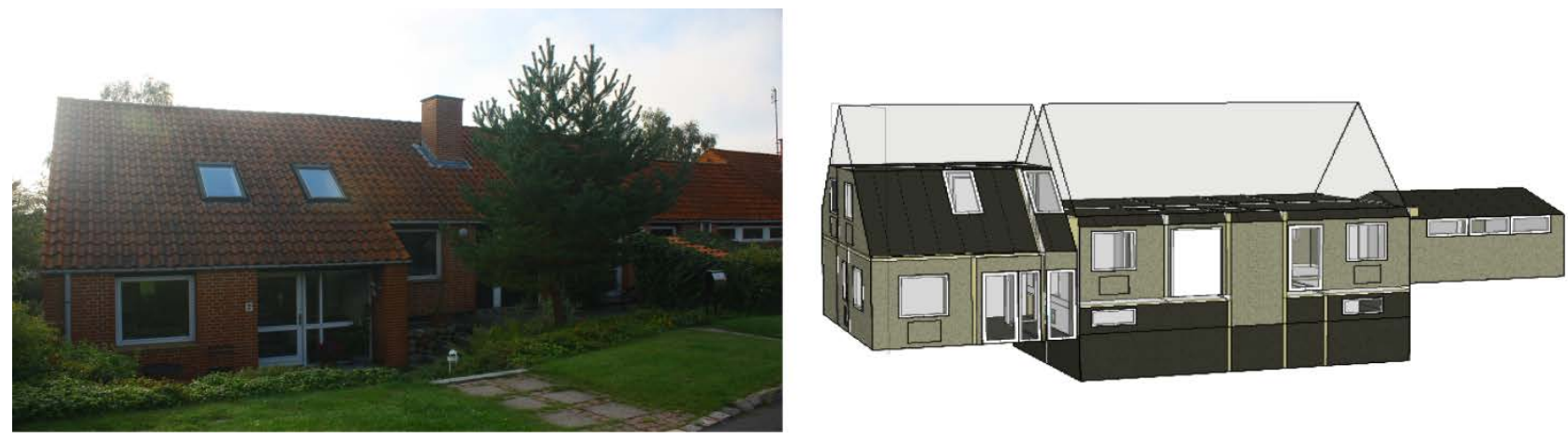
Figure 1 Picture of the case study house (left) and model of the case study house in IDA-ICE (right).

Three occupants live in the house and they were considered to be at home most of the time, because two are retired and the third often studies at home. Electrical equipment was identified during the visit to the house, and all internal heat gains were modelled using specified schedules. The average internal heat gains from equipment, light and occupants in the schedules were $5.2 \mathrm{~W}$ per $\mathrm{m}^{2}$ heated floor area. This corresponds well with the average of $5 \mathrm{~W} / \mathrm{m}^{2}$ that is usually applied for Danish energy calculations [15]. The occupants were assumed to have a standard hot water consumption of $41 \mathrm{~L}$ hot water per person per day [16], and the house was assumed to be naturally ventilated by a fixed air flow of $0.3 \mathrm{l} / \mathrm{s}$ per $\mathrm{m}^{2}$ heated floor area. Real weather data from northern Zealand, Denmark, was obtained from the Danish Metrological Institute and applied in the simulation model. The outdoor temperatures in the period were between 4-11 ${ }^{\circ} \mathrm{C}$ and the sky was overcast.

Assumptions about non-heated spaces such as basements often cause significant uncertainty in simulation programs, so we chose to include the basement in the simulation model [17]. However, the main part of the basement has no heating devices and therefore no temperature set point, so its inclusion only serves the purpose of including the heat loss through the basement constructions. The house is heated by a new condensing natural gas boiler with weather compensation. Heat losses from pipes, hot water tank and boiler, which are all located in the non-heated basement, were estimated to be constant $435 \mathrm{~W}$ based on standard values from [14] and measurements of pipe lengths and insulation thicknesses.

All the radiators in the house were included in the simulation model. The radiators were modelled with well-functioning P-thermostats with a $2^{\circ} \mathrm{C}$ dead band. This corresponds to the actual radiator valves in the house, except for the valves on the radiators in bathroom 1 and in the parents' bedroom that are both manual valves. The radiator in the parents' bedroom is always off, and was therefore also turned off in the simulation model. There was no mass flow control on the radiators in the house and the flow is therefore 
alone controlled by the thermostatic valves. However a theoretical maximum mass flow rate of $0.1 \mathrm{~kg} / \mathrm{s}$ was assumed for each radiator in the model.

To ensure that the simulation model could be used to provide a reliable result, the natural gas consumption was measured during a 6-day measurement period, and compared to the heat consumption calculated by the simulation model during the same period. The natural gas consumption was read from the gas meter as $62.23 \mathrm{~m}^{3}$, which was estimated to correspond to a total heat demand of $646 \mathrm{kWh}$, based on a natural gas heating value of $11 \mathrm{kWh} / \mathrm{Nm}^{3}$ and a boiler efficiency of $106 \%$ [14]. The total heat demand calculated from the simulation model in IDA-ICE was found to be $689 \mathrm{kWh}$. This result was considered sufficiently close for the model to be applicable for the purposes of this investigation.

\subsection{Simulation program}

The case study was conducted by use of the commercially available dynamic building simulation program IDA-ICE (version 4.6.1). IDA-ICE has been validated according to several current standards and can be used to perform advanced simulations of building energy consumption and indoor climate in individual building zones $[18,19]$. The program provides a predefined water radiator unit that can be used for simulation of heat emissions in building zones. The heat emitted from the radiator is calculated according to the heat balance on the water side and the air side of the radiator as given in Equation (1) and Equation (2) respectively.

$$
P=q_{m} \cdot C_{\text {water }} \cdot\left(T_{s}-T_{r}\right)
$$

where

$P$ is the heat flux emitted from the water [W]

$q_{m}$ is the water mass flow rate $[\mathrm{kg} / \mathrm{s}]$

$C_{\text {water }}$ is the specific heat of water $\left[\mathrm{J} / \mathrm{kg}{ }^{\circ} \mathrm{C}\right]$

$T_{s}$ is the supply temperature

$T_{r}$ is the return temperature 


$$
P=K \cdot l \cdot \Delta T_{l o g}^{n}
$$

where

$K$ is a power law coefficient depending on radiator height and width $\left[\mathrm{W} / \mathrm{m}^{\circ} \mathrm{C}\right]$

I is the length of the radiator [m]

$n$ is the radiator exponent [-]

The radiator element can be customized by user input on the geometry, the radiator exponent, and the design heating power of the radiator. Based on these inputs the program calculates the power law coefficient of the radiator and the maximum mass flow rate through the radiator according to the equations above. For simplicity the program allows the user to model the radiator elements without the piping system. In this case pumping power, pressure losses and hydraulic imbalances are not taken into account in the simulation, and the supply temperature at each radiator corresponds to the boiler supply temperature. The piping system was not included in the simulation model of the case study house, which makes it possible to discuss how this simplification affects the simulation results.

The indoor air temperatures calculated by the simulation program are average air temperatures for each zone. This means that the air in each zone is assumed to be perfectly mixed and no temperature gradients are taken into account. This is a common assumption in numerical studies and node-based simulation programs however it should be kept in mind when evaluating the simulation results.

\section{Temperature measurements}

The indoor temperatures, radiator return temperatures, and boiler temperatures in the case house were measured during a 6-day measurement period in November 2014. The outdoor temperatures in the period were between $4-11^{\circ} \mathrm{C}$. The measurements provided useful inputs for the simulation model and made it possible to compare the simulation results to the actual conditions in the case house. The temperatures 
were measured every 10 minutes and the logger equipment had an accuracy of $\pm 0.35{ }^{\circ} \mathrm{C}$, according to the manufacturer.

\subsection{Indoor temperature measurements}

The indoor temperature was measured in each room of the case house. The locations of the temperature loggers are marked on the floorplan in Figure 2. The loggers were often located on furniture in one end of the room, as it was not possible to place the loggers in the middle of the rooms.

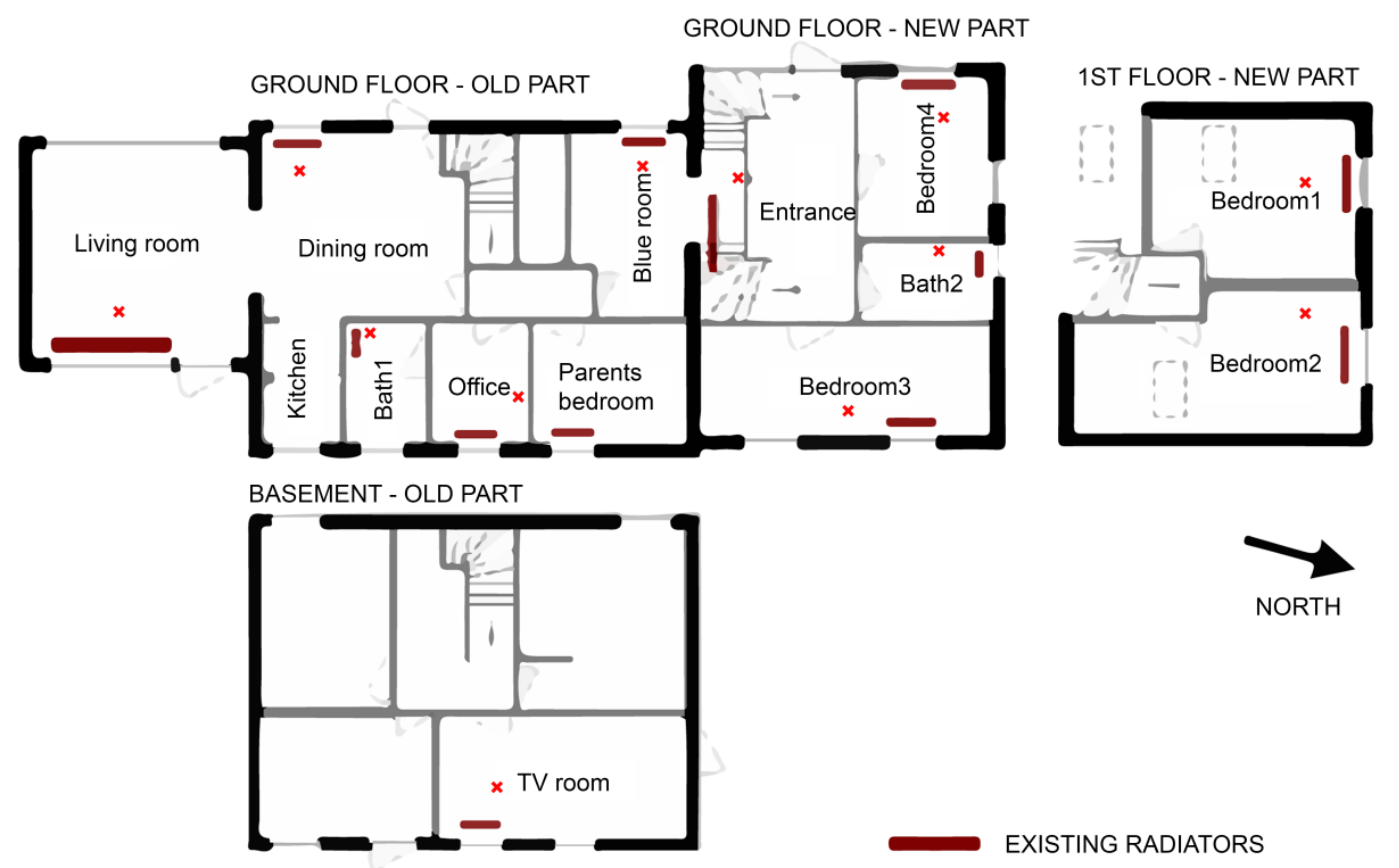

Figure 2 Floorplan of the case-study house showing the ground floor (top left), the basement (bottom), and the first floor (top right).

A small test was carried out to investigate the influence of the logger location on the measured indoor temperature. The indoor temperature was measured at six different locations in the living room, as seen in Figure 3. As seen from the figure, it can be expected that there is a significant vertical and horizontal temperature gradient in some of the rooms. Temperatures that were measured in one end of the room were found to differ from the temperature measured in the middle of the room by up to $1.2{ }^{\circ} \mathrm{C}$. The temperature gradient was mainly assumed to play a significant role in rooms with a large volume, such as 
the living room, or rooms where there are not radiators below all windows, such as in the Dining room/Kitchen, the TV room, the Entrance and Bath1.

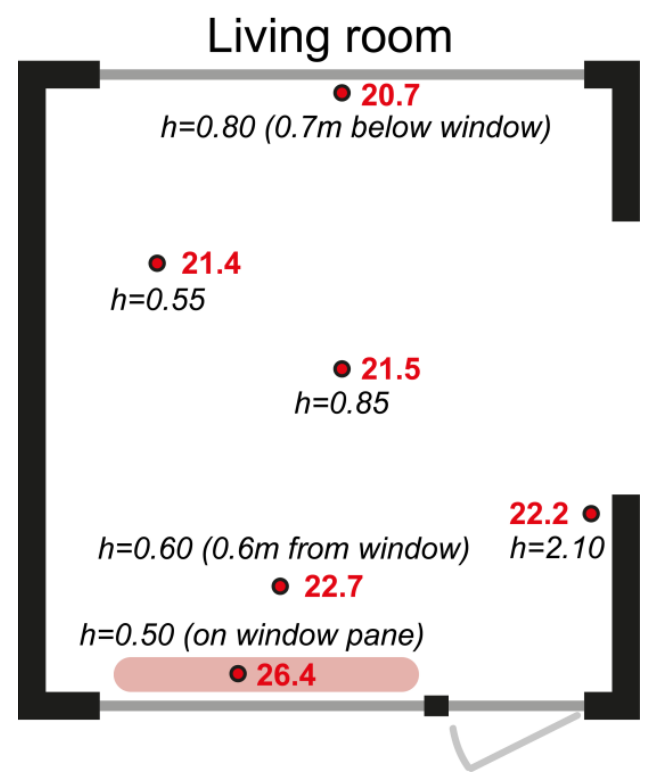

Figure 3 Indoor temperatures measured at six different locations in the living room.

\subsection{Return temperature measurements}

The heating system temperatures were made using temperature loggers equipped with temperature probes. The temperature probes were attached to the outlet pipes of the various radiators and covered with insulation to measure an approximate temperature of the return water. Additional loggers were connected to the supply and return pipes at the natural gas boiler. Pictures showing the measurement equipment and setup can be seen in Figure 4. 

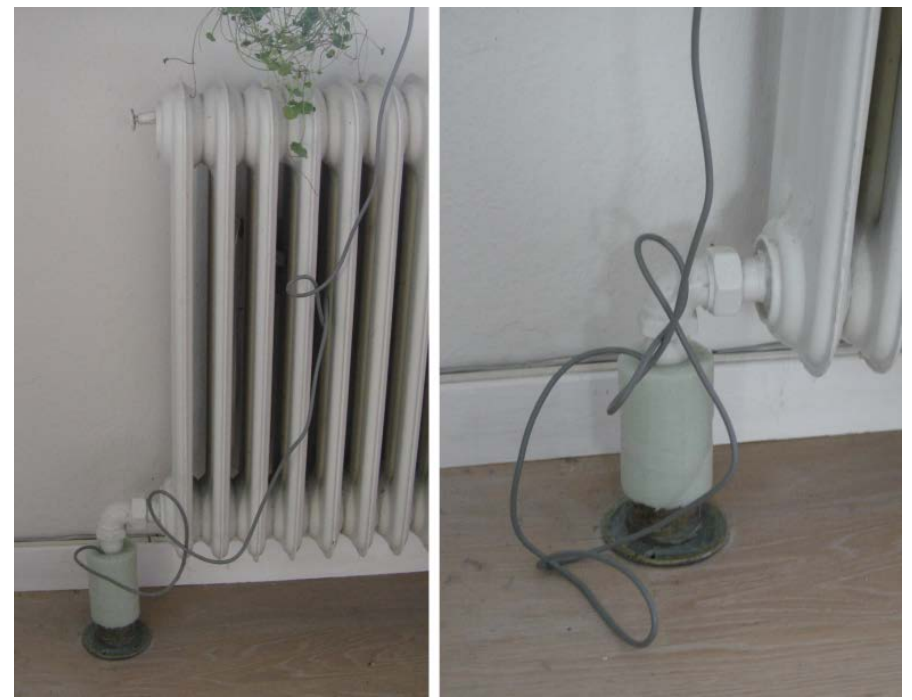

Figure 4 Pictures of the measurement setup. The pictures illustrate the mounting of the temperature probe to the outlet pipe of the radiator.

The accuracy of the measurement method was evaluated through two tests. In the first test, the temperature of a radiator pipe was measured with three different loggers at the same time, in order to evaluate the inaccuracy due to the probe location under the insulation. Secondly, the temperatures measured with the illustrated logger setup were compared to temperatures measured with a laser pointer. The tests showed that the difference between the temperatures measured by three different loggers connected to the same pipe was up to approximately $2{ }^{\circ} \mathrm{C}$. Furthermore the difference between the temperatures measured with the given measurement setup and those measured with a laser pointer were $0.4-4.2^{\circ} \mathrm{C}$. The measurement method was therefore assumed to have an inaccuracy of up to approximately $6^{\circ} \mathrm{C}$. This means that the measurements could not be used for a validation of the simulation models. Instead they were used to provide an indication of the actual heating system temperatures in the case house.

\section{Simulation assumptions}

In order to investigate the significance of typical assumptions applied in simulations dealing with lowtemperature radiator heating, a number of simulations were performed based on various calculation 
assumptions. Typical assumptions that were investigated in the study can be divided in the following three categories:

1 Method chosen for calculation of heat emissions from radiators

2 Method chosen for estimation of the design heating power of existing radiators

3 Indoor temperature set-points applied in the simulations

The theory behind the calculation of heat emissions from radiators and estimation of design heating power of existing radiators is described in the next sections. Furthermore the simulation assumptions that were investigated in the study are described in detail.

\subsection{Calculation of heat emissions}

The heat emitted from a given radiator is usually defined by test measurements and stated by the manufacturer in product catalogues. The tests are carried out for a number of standard mean temperature differences and using a fixed water mass flow rate. In the current standard, EN 442-2 [20], the tests are carried out with a water mass flow rate corresponding to the temperatures $75 / 65 / 20^{\circ} \mathrm{C}$ for supply, return and air temperature respectively. In practice the operating temperatures differ from the test temperatures and therefore so does the water mass flow rate. The actual heat emitted from a radiator can be calculated using Equation (3) based on the mean temperature difference (MTD) between radiator and surroundings.

$$
\phi=\left(\frac{\Delta T}{\Delta T_{0}}\right)^{n} \cdot \phi_{0}
$$

where

$\Phi_{0}$ is the design heating power at the standard test conditions [W]

$\Phi$ is the heating power at the operating temperatures [W]

$\Delta T_{0}$ is the MTD between radiator and surroundings in the standard test conditions $\left[{ }^{\circ} \mathrm{C}\right.$ ]

$\Delta T$ is the MTD between radiator and surroundings at the operating temperatures [ ${ }^{\circ} \mathrm{C}$ ]

$n$ is the radiator exponent [-] 
The mean temperature difference is the difference between the temperature of the radiator and the temperature of the air. The temperature difference is the driver of the heat emissions and is therefore an important factor in the calculation of the heating power. The temperature difference is based on a mean radiator temperature, since radiators are usually warm at the top and colder near the bottom. One way of calculating the temperature difference between the mean radiator temperature and the air temperature $\left(T_{i}\right)$ is by using the arithmetic mean temperature difference. The arithmetic mean temperature difference is described in EN 442-2 and calculated in accordance with Equation (4).

$$
\text { Arithmetic mean temperature difference }=\Delta T_{\text {arit }}=\frac{T_{s}+T_{r}}{2}-T_{i}
$$

However, the arithmetic mean temperature difference does not provide a precise estimation of the mean radiator temperature if there is a large difference between the supply and the return temperature. This is due to the fact that the temperature distribution over the radiator surface is not linear. A more precise method is to use the logarithmic mean temperature difference, which is calculated in accordance with Eq. (5).

$$
\text { Logarithmic mean temperature difference }=\Delta T_{\log }=\frac{T_{s}-T_{r}}{\ln \left(\frac{T_{s}-T_{i}}{T_{r}-T_{i}}\right)}
$$

\subsubsection{Radiator exponent}

The relation between the mean temperature difference and the heat output of the radiator is described by the radiator exponent. This exponent is important since the relationship between the two is non-linear. The radiator exponent can be derived by testing the radiator at different temperature sets and using Eq. (3) to determine the exponent that describes the relation between the measured heat outputs. The exact radiator exponent differs slightly for different types and sizes of radiators. Typical radiators with a height above $0.4 \mathrm{~m}$ have a radiator exponent of approximately 1.3 , which is an applicable assumption for standard situations. However, according to recent findings it may not be applicable to use the radiator exponent found during standard test conditions to calculate heat emissions in special cases like low-temperature 
heating [13]. Instead the radiator exponent should be varied depending on the relative cooling of the radiator. This is due to the fact that the nature of the heat emissions change when the mass flow rate and the turbulence of the water in the radiator changes. The relative cooling of a radiator with certain operating temperatures can be calculated using Equation (6).

$$
\text { Relative cooling }=\frac{T_{s}-T_{r}}{T_{s}-T_{i}}
$$

The relationship between the relative cooling of a plate or a column radiator and the radiator exponent can be assumed to approximate the curve shown in Figure 5, as found by [13]. The given curve can be assumed to apply for typical radiators with a height above $400 \mathrm{~mm}$. However it must be underlined that the curve does not apply for convector type radiators with a height below $400 \mathrm{~mm}$, where the radiator exponent was found to increase with increasing relative cooling.

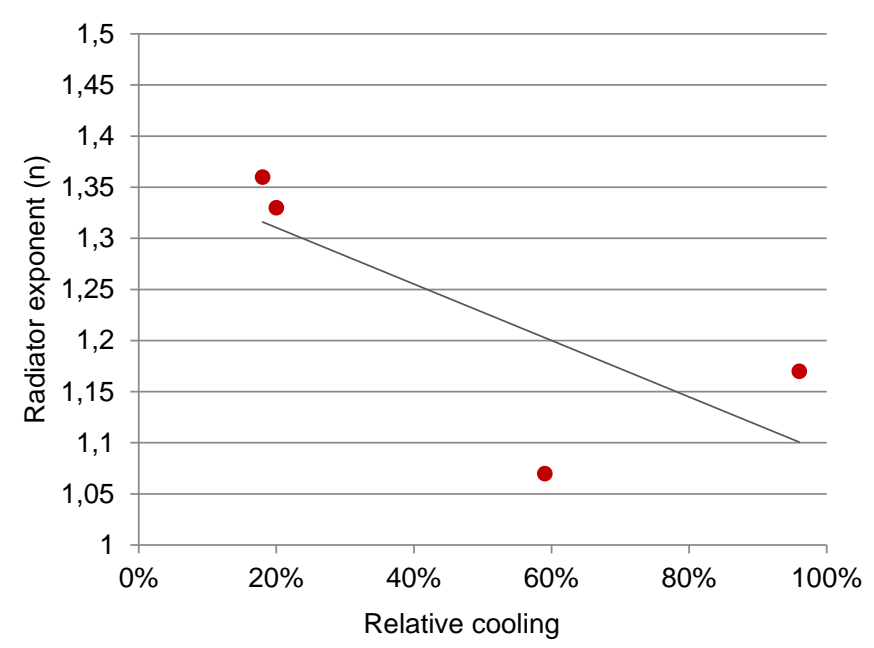

Figure 5 Relationship between relative cooling and radiator exponent for a Type 22 radiator [13]

This means that, for a Type 22 radiator operated with temperatures of $55 / 25 / 20^{\circ} \mathrm{C}$, the relative cooling is $86 \%$ and the accurate radiator exponent describing the heat emitted from the radiator is closer to $n=1.15$, than the standard $n=1.3$. This study evaluated which effect the accuracy of the radiator exponent and the choice of method for calculation of the MTD had on the simulation results. Three different simulations were performed using either the logarithmic MTD or the arithmetic MTD and either a radiator exponent of 
1.3 or an exact radiator exponent to calculate the heat emissions from the radiators. The exact radiator exponent was estimated by use of Figure 7 based on a calculation of the relative cooling of each radiator according to the measured supply and return temperatures.

\subsection{Design heating power of existing radiators}

When investigating the potential to heat an existing building with lower temperatures it is necessary to estimate the heating power of the existing heating elements. The most accurate procedure for estimating the design heating power of the radiators in an existing building is to visit the specific building and identify the actual radiator types and sizes. However it is not always possible to get access to the building. In that case the design heating power of the existing radiators can be estimated based on construction drawings of the house or calculations of the design heat loss in the house. In this study we tested three different methods for estimating the design heating power of the radiators in the case house and investigated how each method affected the simulation results.

\subsubsection{Actual radiator sizes}

For the first method the radiators in the case house were characterized and measured during a visit to the house. The design heating power of each radiator was estimated using an Excel program based on empirical data from tests of typical Danish radiators. The program was acquired from the Danish Technological Institute. According to tests performed by the Danish Technological Institute, the general accuracy of the program was $\pm 5 \%$, though in a few cases, the inaccuracy of the program was as much as 10 $15 \%$.

The radiators in the case house are listed in Table 1. The design heating power of the radiators is given for the temperature set $90 / 70 / 20^{\circ} \mathrm{C}$ which was the standard design temperature set in Denmark in the mid1900 s.

Table 1 Radiator types and sizes in the case study house with estimated design heating power of each radiator 


\begin{tabular}{|c|c|c|c|c|c|c|}
\hline Location & $\begin{array}{l}\text { Height } \\
{[\mathrm{m}]}\end{array}$ & $\begin{array}{l}\text { Depth } \\
{[\mathrm{m}]}\end{array}$ & $\begin{array}{l}\text { Length } \\
{[\mathrm{m}]}\end{array}$ & $\begin{array}{l}\text { No. of } \\
\text { columns }\end{array}$ & Type & $\begin{array}{l}\text { Design heating power, } \Phi_{0} \text { at } \\
90 / 70 / 20^{\circ} \mathrm{C}[\mathrm{W}]\end{array}$ \\
\hline Living room & 0.35 & 0.25 & 2.0 & 50 & \multirow[t]{6}{*}{ Column } & 4230 \\
\hline Dining room & 0.55 & 0.14 & 0.78 & 20 & & 1530 \\
\hline Bathroom 1 & 0.6 & 0.14 & 0.42 & 11 & & 900 \\
\hline Parents' bedroom & 0.55 & 0.14 & 0.78 & 20 & & 1530 \\
\hline Office & 0.55 & 0.14 & 0.78 & 20 & & 1530 \\
\hline Blue room & 0.55 & 0.14 & 0.78 & 20 & & 1530 \\
\hline Entrance & 0.4 & 0.1 & 1.2 & - & \multirow{7}{*}{$\begin{array}{l}\text { Plate (Type } 22 \\
-2 \text { plates and } \\
2 \text { convector } \\
\text { panels) }\end{array}$} & 1930 \\
\hline Bedroom 4 & 0.6 & 0.1 & 0.8 & - & & 1870 \\
\hline Bedroom 3 & 0.6 & 0.1 & 1.0 & - & & 2330 \\
\hline Bedroom 2 & 0.6 & 0.1 & 1.0 & - & & 2330 \\
\hline Bedroom 1 & 0.6 & 0.1 & 1.0 & - & & 2330 \\
\hline Bathroom 2 & 0.6 & 0.1 & 0.3 & - & & 700 \\
\hline Basement & 0.66 & 0.1 & 0.78 & - & & 1970 \\
\hline
\end{tabular}

\subsubsection{Construction drawings}

The second method was based on an estimation of the design heating power of the radiators by use of the construction drawings of the house. This is only possible if adequate drawings including the original radiators are available. This method includes the risk that old radiators have been replaced with newer models, or that some old radiators have been removed altogether, if large internal refurbishments have been carried out such as walls being knocked down to combine a number of rooms into one.

The drawings of the case house included all of the radiators that were in the house today, apart from the radiator in the basement. Furthermore the drawings included two extra plate radiators in the dining room, because this room used to be three separate rooms. When the heating power of the extra radiators were included, while the heating power of the radiator in the basement was removed, the total design heating power in the house was reduced by $1100 \mathrm{~W}$.

\subsubsection{Calculation of design heat loss}

The third method was to estimate the design heating power of the existing radiators based on calculations of the design heat loss of the building. In this case, the radiators are assumed to be dimensioned to cover the design heat loss of each room at given design temperatures. However, it may be difficult to identify 
realistic design temperatures for old radiator systems, because commonly applied temperatures have differed both over time and depending on the original heating source of the house. For houses heated with natural gas, it was customary in Denmark to use design temperatures of $90 / 70^{\circ} \mathrm{C}$. By 1990 , the design temperatures had changed to $80 / 60^{\circ} \mathrm{C}$ and, around 1995 , the design temperatures were lowered even further to $62.5 / 47.5^{\circ} \mathrm{C}$ [21]. In district heating areas, the design temperatures are determined by the district heating company and may therefore vary around the country. For many years, it has been common to use a design temperature set of $70 / 40^{\circ} \mathrm{C}$ for radiators in buildings supplied by district heating. This design temperature set was also included in the building code in 1995 [22]. This method therefore includes in-built inaccuracy due to assumption about design temperatures. Furthermore, the method assumes that current practices can be used to estimate the design heat loss used for dimensioning of radiators even in houses constructed many years ago. This may also cause some bias because the procedures for the calculation of heat loss changed many times during the 1900s. Earlier, it may also have been custom that radiators in small houses were dimensioned by a blacksmith using a rule-of-thumb approach resulting in general overdimensioning.

The design heat loss for all rooms in the case house were calculated in accordance with Danish design conditions using an indoor temperature set point of $20^{\circ} \mathrm{C}$, an outdoor temperature of $-12^{\circ} \mathrm{C}$, and without any heat gains. The design heating power of the radiators was estimated for two different sets of design temperatures. In the first calculations the design heating power was calculated for a design temperature set of $90 / 70^{\circ} \mathrm{C}$ in the old part of the house and $80 / 60^{\circ} \mathrm{C}$ in the new part of the house, according to the age of the two building parts. In the second calculation, the radiators were dimensioned for a design temperature set of $70 / 40^{\circ} \mathrm{C}$. This meant that the design heating power of the radiators in the second calculation was larger than that in the first calculation, because larger radiator dimensions are required to cover the same heat loss with a lower temperature set. 
Table 2 shows a summary of the design heating power of the radiators in the house for the different calculation methods at a design temperature set of $90 / 70 / 20^{\circ} \mathrm{C}$.

Table 2 Design heating power in the house calculated using 4 different methods

\begin{tabular}{|c|c|c|c|c|}
\hline \multirow[b]{2}{*}{ Scenario } & \multicolumn{4}{|c|}{$\begin{array}{l}\text { Total design heating power at temperatures } \\
90 / 70 / 20^{\circ} \mathrm{C}[\mathrm{kW}]\end{array}$} \\
\hline & Old part & New part & Basement & Total \\
\hline Design heating power based on actual radiator sizes & 11.24 & 11.49 & 1.97 & 24.70 \\
\hline $\begin{array}{l}\text { Design heating power based on radiators included in } \\
\text { drawings of the case house }\end{array}$ & 12.11 & 11.49 & 0 & 23.60 \\
\hline $\begin{array}{l}\text { Design heating power based on design heat loss and } \\
\text { design temperatures of } 90 / 70^{\circ} \mathrm{C} \text { in the old part of the } \\
\text { house and } 80 / 60^{\circ} \mathrm{C} \text { in the new part of the house }\end{array}$ & 9.05 & 5.50 & 0 & 14.55 \\
\hline $\begin{array}{l}\text { Design heating power based on design heat loss and } \\
\text { design temperatures of } 70 / 40^{\circ} \mathrm{C}\end{array}$ & 19.65 & 9.38 & 0 & 29.03 \\
\hline
\end{tabular}

\subsection{Indoor temperatures}

The indoor temperature set-point is an important input for studies on low-temperature heating. This is due to the fact that the heat demand in a given room and the heat emitted from a radiator is largely dependent on the indoor temperature. This study investigated how assumptions on the indoor temperature set-point affected the analysis of a low-temperature heating system. First a simulation was performed where the indoor temperature set-point in all rooms was given as $20{ }^{\circ} \mathrm{C}$ corresponding to the indoor temperature required in the Danish Building Code. Secondly a simulation was performed where indoor temperature setpoints in the house were based on actual measured indoor temperatures.

\subsection{Scenarios}

The simulation model in IDA-ICE was all together used to investigate 7 different scenarios for how to simulate low-temperature heating in the case study house. The scenarios represented different variations on how to calculate the heat emissions from the radiators, how to estimate the design heating power of existing radiators, and how to estimate the indoor temperature set-points. The scenarios were split in two categories: Category A deals with different methods for calculation of heat emissions, while Category B 
deals with different methods for estimation of design heating power. The scenarios are summarized in Table 3.

Table 3 Scenarios for the calculation of return temperatures investigated in the simulation model

\begin{tabular}{|c|c|c|c|c|c|}
\hline Scenario & Category & $\begin{array}{l}\text { Radiator } \\
\text { exponent (n) }\end{array}$ & \begin{tabular}{|l|} 
Mean \\
temperature \\
difference \\
\end{tabular} & $\begin{array}{l}\text { Indoor } \\
\text { temperature set- } \\
\text { point }\end{array}$ & $\begin{array}{l}\text { Method for } \\
\text { design heating } \\
\text { power }\end{array}$ \\
\hline A1 & \multirow{4}{*}{$\begin{array}{l}\text { Calculation } \\
\text { of heat } \\
\text { emissions }\end{array}$} & $\begin{array}{l}\text { According to } \\
\text { measurements }\end{array}$ & Logarithmic & $\begin{array}{l}\text { According to } \\
\text { measurements }\end{array}$ & Actual radiators \\
\hline $\mathrm{A} 2$ & & $\mathrm{n}=1.3$ & Logarithmic & $\begin{array}{l}\text { According to } \\
\text { measurements }\end{array}$ & Actual radiators \\
\hline A3 & & $\mathrm{n}=1.3$ & Arithmetic & $\begin{array}{l}\text { According to } \\
\text { measurements }\end{array}$ & Actual radiators \\
\hline A4 & & $\mathrm{n}=1.3$ & Logarithmic & $20^{\circ} \mathrm{C}$ & Actual radiators \\
\hline B1 & \multirow{3}{*}{$\begin{array}{l}\text { Estimation } \\
\text { of design } \\
\text { heating } \\
\text { power }\end{array}$} & $\mathrm{n}=1.3$ & Logarithmic & $\begin{array}{l}\text { According to } \\
\text { measurements }\end{array}$ & Drawings \\
\hline B2 & & $\mathrm{n}=1.3$ & Logarithmic & $\begin{array}{l}\text { According to } \\
\text { measurements }\end{array}$ & $\begin{array}{l}\text { Design heat loss } \\
(90 / 70 \text { and } 80 / 60)\end{array}$ \\
\hline B3 & & $\mathrm{n}=1.3$ & Logarithmic & $\begin{array}{l}\text { According to } \\
\text { measurements }\end{array}$ & $\begin{array}{l}\text { Design heat loss } \\
(70 / 40)\end{array}$ \\
\hline
\end{tabular}

The results from the simulations were evaluated from two different aspects. First the indoor temperatures measured in the case house were compared to the operative indoor temperature calculated by the simulation scenario A1. This scenario was expected to be the scenario that was closest to the actual situation in the house. The aim of the comparison was to evaluate how well the simulation model with the given assumptions was found to resemble reality. Secondly the calculated heating system temperatures in all simulation scenarios were compared to the actual heating system temperatures measured in the house. The aim of this comparison was to evaluate how different assumptions affect the calculation of heating system temperatures. The heating system supply temperature was based on the actual supply temperature measured in the case house, and this temperature was the same in all models. The evaluation therefore focused on the return temperatures from each radiator in the case house and from the overall heating system.

\section{Results and discussion}

\subsection{Calculated indoor temperatures}


Figure 6 shows the measured indoor temperatures in the case house along with the calculated average indoor air temperatures according to Scenario A1.

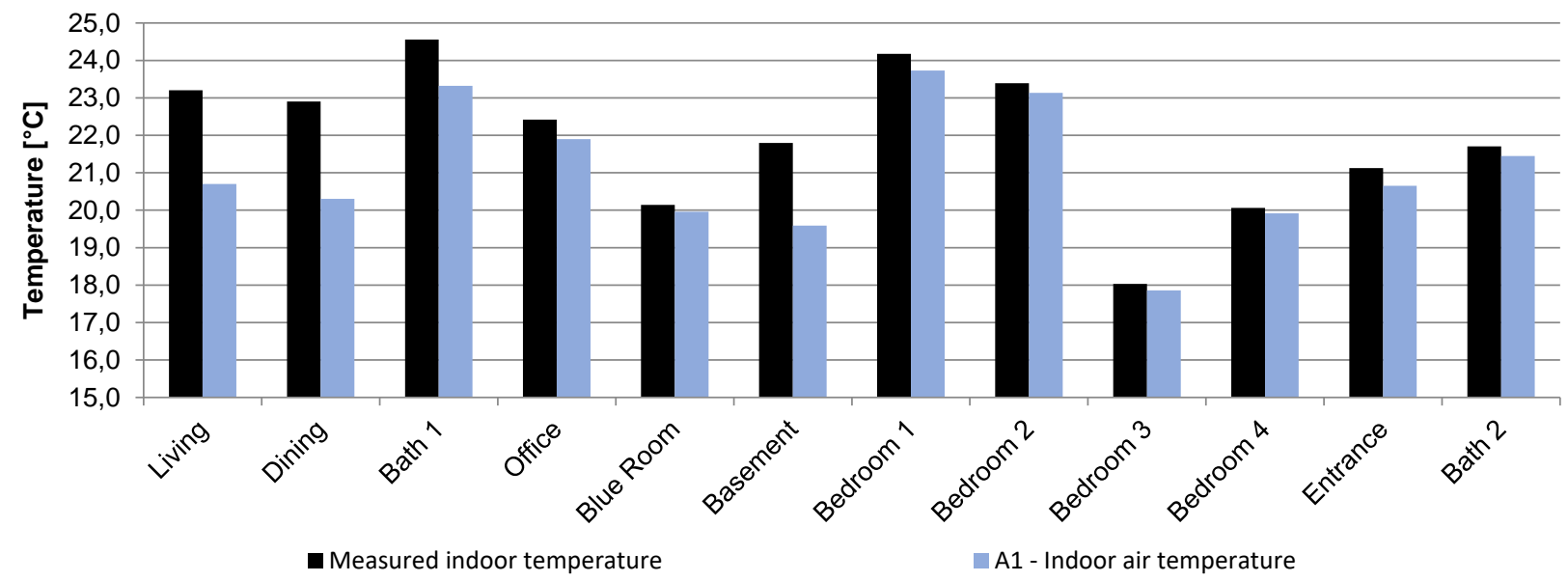

Figure 6 Measured temperatures in the rooms of the case house compared to calculated average indoor temperatures according to Scenario A1.

The figure shows that the calculated indoor temperatures in the living room, the dining room, the basement, and bath1 were lower than the measured indoor temperatures. This indicates that the heating powers of the radiators included in these rooms of simulation model, are too small to maintain the measured indoor temperature. However the uncertainties in the estimation of the radiator heating power are not expected to be the main reason for the difference between the calculated and the measured indoor temperatures in these rooms. Since the temperature difference is mainly found in large rooms where the logger location can be expected to cause the measured temperature to be higher than the average, it is expected that the difference can be explained by the uncertainties in the indoor temperature measurements. The results therefore highlight that the uncertainty of indoor temperature measurements and the simplification of the indoor temperature calculations, must be kept in mind when the results from node-based simulation tools are evaluated.

\subsection{Calculated return temperatures}

\subsubsection{Scenario A}


The calculated average return temperatures from the radiators in the case house according to Scenario A1A4 are shown in Figure 7 alongside the average measured return temperatures.

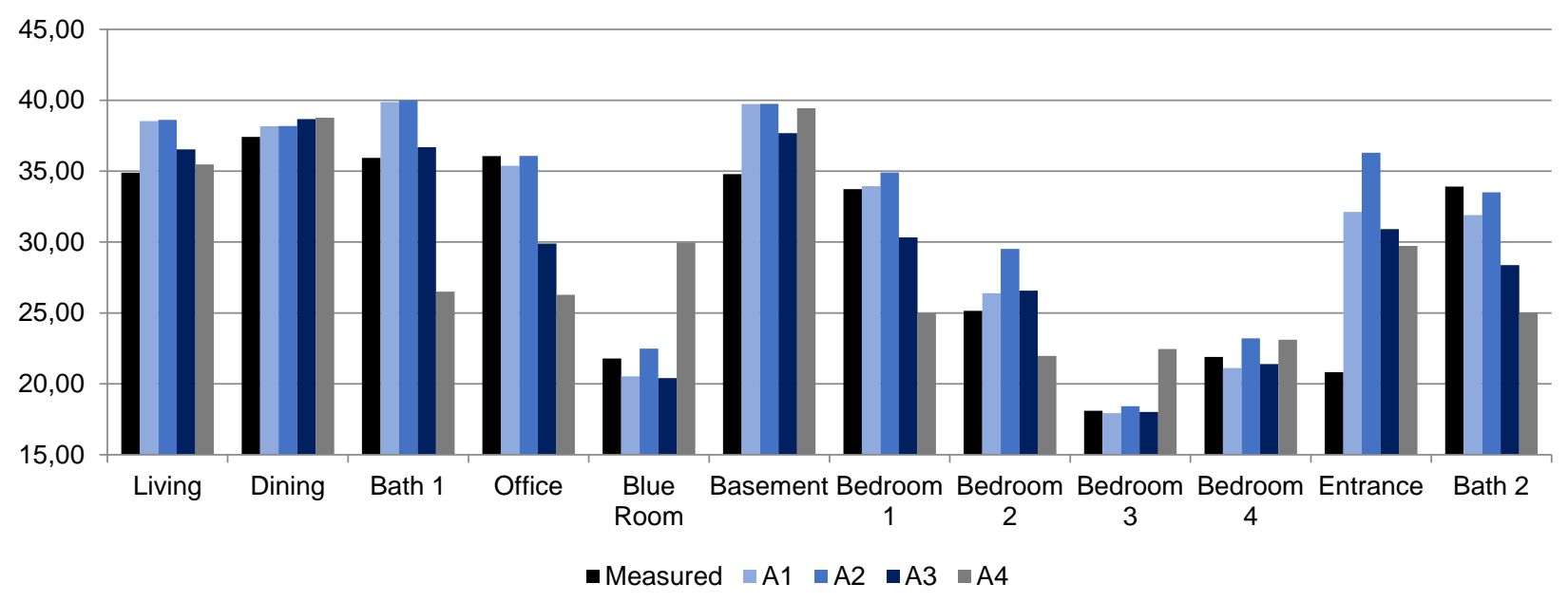

Figure 7 Return temperatures from all radiators in the case house as measured and calculated from Scenarios A1-A4.

As seen from the figure the scenarios $A 1$ and $A 2$ provided almost similar results and showed a good correspondence with the measured temperatures. The return temperature from the radiator in the entrance was the only temperature that the scenarios failed to provide a reasonable estimation of. However the return temperature from this radiator was not accurately estimated by any of the scenarios, which was found to be due to fact that the thermostatic valve on this radiator was almost closed, thereby causing the entrance to be partly heated by radiators in adjacent rooms. This indicates that the detailed simulation model can provide reasonable calculations of the radiator return temperatures, but it cannot be used to estimate return temperatures in cases where occupant behaviour causes this type of malfunction. The maximum deviations between the calculated and the measured return temperatures in Scenarios A1 and $\mathrm{A} 2$ were approximately $4-5^{\circ} \mathrm{C}$, if the radiator in the entrance is not taken into account. The largest deviations were found on the return temperatures from the radiators in the living room, the basement, and bath1. These radiators were found to have a high calculated mass flow rate and therefore the deviation may partly be caused by the high maximum mass flow that was assumed in the model. Furthermore part of the difference may be explained by measurement inaccuracies as the mounting of the temperature probe 
on the radiator pipes may cause the measured temperatures to be lower than the actual return temperatures. The difference could also be explained by the fact that the piping system and the heat losses from the pipes were not included in the simulation model. However the results indicate that the simulation model can be used to provide reasonable estimates of the heating system temperature despite of this simplification.

The return temperatures estimated in Scenario A3 where the arithmetic MTD was used did not differ significantly from the temperatures estimated in Scenarios A1 and A2. The main difference in the calculated return temperatures was found for the radiators in the office, bedroom1, and bath2. Scenario A3 estimated the return temperatures from these radiators to be up to $6{ }^{\circ} \mathrm{C}$ lower than the measured temperatures and the temperatures estimated in scenario $\mathrm{A} 1$ and $\mathrm{A} 2$.

Generally it was found that the use of the standard radiator exponent in Scenario A2 resulted in slightly higher calculated return temperatures than those from Scenario A1. Scenario A3 that was based on calculations with the arithmetic mean temperature difference resulted in slightly lower calculated return temperatures. While Scenario A2 thereby provided results that were on the safe side, Scenario A3 slightly overestimated the heating power of the radiators.

The return temperatures calculated in Scenario A4 showed the largest deviations from the return temperatures calculated in the remaining scenarios and from the measured return temperatures. The method was found to underestimate the return temperatures by $8-9{ }^{\circ} \mathrm{C}$ in rooms such as the office, bath 1 , and bedroom1, where the measured indoor temperature set-points were high. Also the return temperatures were over-estimated in rooms where the measured indoor temperature set-points were below $20^{\circ} \mathrm{C}$. The indoor temperature set-points were thereby seen to have a large effect on the accuracy of the calculated return temperatures. The effect might be especially visible in this study, as the rooms of the case house were found to have very different indoor temperature set-points ranging between $18-24^{\circ} \mathrm{C}$. The 
simulation performed in Scenario A4 may therefore not be useful to estimate actual radiator return temperatures. However it could be useful to identify the most substantial problems with a high radiator return temperature, as seen for the radiators in the living room, the dining room, and the basement.

\subsubsection{Scenario B}

Figure 8 shows the calculated average return temperatures from the radiators in the case house according to Scenario B1-B3 along with the measured average return temperatures. The basement radiator was not included in these simulations as the basement was not planned to be heated at the time of construction.

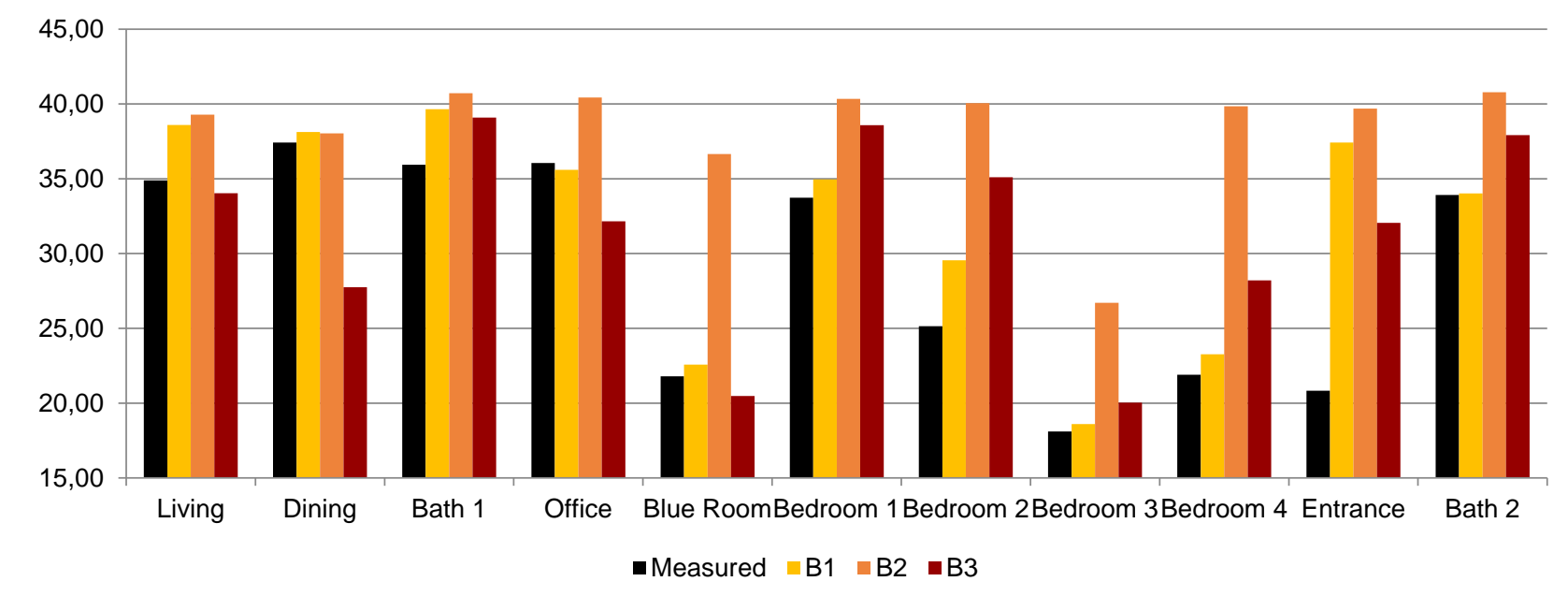

Figure 8 Return temperatures from all radiators in the case study house as measured and calculated from Scenarios B1-B3.

The results from Scenario B1 showed only minor deviations in the calculated return temperatures compared to Scenario A1. This was due to the fact that the extra radiators that were included in the drawings of the case house were not big enough to influence the calculated return temperatures.

The return temperatures calculated in both scenarios B2 and B3 were found to differ greatly from the measured temperatures and the return temperatures estimated in the remaining scenarios. The use of high design temperatures in Scenario B2 was found to cause an overestimation of the return temperatures from the radiators in the new part of the house. Similarly the use of design temperatures of $70 / 40{ }^{\circ} \mathrm{C}$ in Scenario B3 caused an underestimation of the return temperatures from the radiators in the old part of the house. 
The differences between the calculated return temperatures and the measured return temperatures in the scenarios were found to be up to approximately $18{ }^{\circ} \mathrm{C}$ and $10{ }^{\circ} \mathrm{C}$ respectively. These methods were therefore not found to be suited to calculate accurate heating system return temperatures. While Scenario B2 provided results that were on the safe side, Scenario B3 on the other hand was found to over-estimate the heating power in the house.

\section{3 heating system temperatures}

The average measured boiler temperatures in the case house are seen in Figure 9 along with the boiler temperatures calculated in all scenarios. As seen from the figure the calculated boiler return temperatures were all between $36^{\circ} \mathrm{C}$ and $40{ }^{\circ} \mathrm{C}$. All of the Scenarios were thereby seen to provide reasonable estimates of the overall boiler return temperature. The high return temperatures and high water mass flow rates that were calculated in some of the radiators in the investigated case study house may however be part of the reason for the small difference. In that case the assumptions on maximum water mass flow in the radiators may have a significant influence on this result. Even though all the Scenarios were found to provide a reasonable estimate of the boiler return temperature, it does therefore not mean that all the Scenarios represent suitable calculation methods. This is underlined by the differences in the calculated return temperatures from the individual radiators.

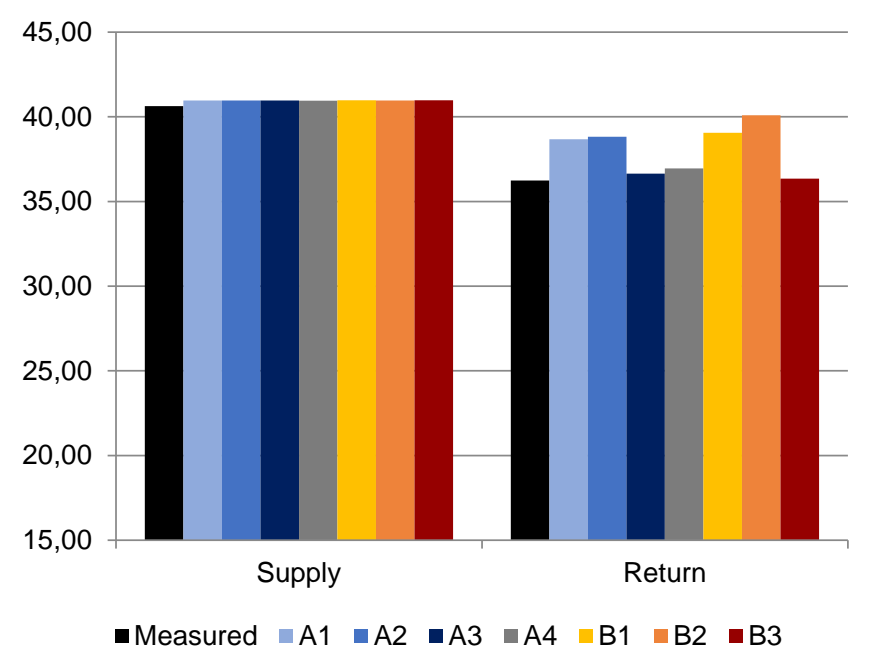


Figure 9 Average boiler return temperature measured and calculated from the scenarios.

\section{Conclusions}

This study showed that the detail level and assumptions included in a simulation model have a large impact on the simulation results of studies on low-temperature heating in existing buildings. The calculated radiator return temperatures were found to differ by up to $16{ }^{\circ} \mathrm{C}$ depending on the model assumptions Furthermore the difference between the calculated and the measured return temperatures were found to be up to $18^{\circ} \mathrm{C}$ in some cases. However the results of the study indicated that a simulation model can be used to provide reasonable estimates of the heating system temperatures if actual radiator sizes and reasonable indoor temperature set-points are included in the model.

The study showed that it is complex to estimate and model actual indoor temperatures and temperature set-points. At the same time these inputs were found to have a large effect on the calculated return temperatures in the simulation model. A simulation based on a standard indoor temperature of $20{ }^{\circ} \mathrm{C}$ was not found to provide a good estimation of the heating system temperatures. The method could be used to identify radiators that are likely to cause a high return temperature, but it did not provide a good estimate of the actual return temperatures from the radiators. It can be useful to base the simulation model on measured indoor temperatures however the uncertainties related to this type of measurements should be kept in mind.

The case study showed that it was necessary to include the actual radiator sizes in the simulation in order to obtain accurate results. Estimating the radiator sizes based on calculations of design heat loss was found to cause the calculated heating system temperatures to differ greatly from the measured temperatures. The use of simplified standard methods for calculation of the heat emissions from the radiators was not found to cause significant differences in the calculated heating system temperatures.

\section{Acknowledgements}


The work presented in this article was a result of the research activities of the Strategic Research Centre for 4th Generation District Heating (4DH), which received funding from the Innovation Fund Denmark. An extra thank-you is due to Kristian Kærsgaard Hansen and especially Otto Paulsen from the Danish Technological Institute for providing information on the design heating power of old radiators and commenting on the work presented in this article. 


\section{References}

[1] Eurostat, Consumption of energy, (2015). http://ec.europa.eu/eurostat/statisticsexplained/index.php/Consumption_of_energy\#Consumption (accessed November 18, 2015).

[2] M. Maivel, J. Kurnitski, Low temperature radiator heating distribution and emission efficiency in residential buildings, Energy Build. 69 (2014) 224-236. doi:10.1016/j.enbuild.2013.10.030.

[3] W. Richter, A. Meinzenbach, M. Knorr, LowEx Fernwärme - Multilevel district heating - Einfluss sinkender Vorlauftemperatur auf die gebäudetechnik [Multilevel district heating - The influence of lower supply temperature on the building installations], AGFW, Dresden, 2010.

[4] H. Lund, S. Werner, R. Wiltshire, S. Svendsen, J.E. Thorsen, F. Hvelplund, et al., 4th Generation District Heating (4GDH): Integrating smart thermal grids into future sustainable energy systems, Energy. 68 (2014) 1-11. doi:10.1016/j.energy.2014.02.089.

[5] Danish Energy Agency, EUDP 2010-II, Demonstration i Lystrup - Fuldskalademonstration af lavtemperaturfjernvarme i eksisterende bebyggelser - Journalnr. 64010-0479 [Demonstration in Lystrup - Full scale demonstration of low-temperature district heating in existing building areas], 2014.

[6] A. Hesaraki, S. Holmberg, Energy performance of low temperature heating systems in five new-built Swedish dwellings: A case study using simulations and on-site measurements, Build. Environ. 64 (2013) 85-93. doi:10.1016/j.buildenv.2013.02.009.

[7] M. Brand, S. Svendsen, Renewable-based low-temperature district heating for existing buildings in various stages of refurbishment, Energy. 62 (2013) 311-319. doi:10.1016/j.energy.2013.09.027.

[8] M. Harrestrup, S. Svendsen, Changes in heat load profile of typical Danish multi-storey buildings when energy-renovated and supplied with low-temperature district heating, Int. J. Sustain. Energy. 34 (2013) 232-247. doi:10.1080/14786451.2013.848863.

[9] Z. Nagy, D. Rossi, C. Hersberger, S.D. Irigoyen, C. Miller, A. Schlueter, Balancing envelope and heating system parameters for zero emissions retrofit using building sensor data, Appl. Energy. 131 (2014) 56-66. doi:10.1016/j.apenergy.2014.06.024.

[10] I. Sârbu, Energy analysis of low temperature heating systems, WSEAS Trans. Heat Mass Transf. 5 (2010) 123-132.

[11] A. Hasan, J. Kurnitski, K. Jokiranta, A combined low temperature water heating system consisting of radiators and floor heating, Energy Build. 41 (2009) 470-479. doi:10.1016/j.enbuild.2008.11.016. 
[12] Danish Energy Agency, EUDP 2008-II, CO2-reductions in low energy buildings and communities by implementation of low-temperature district heating systems. Demonstration cases in EnergyFlexHouse and Boligforeningen Ringgården - Journalnr. 63011-0152, DTU BYG, 2011. http://www.byg.dtu.dk/Publikationer/Byg_rapporter.aspx.

[13] O. Paulsen, F. Rosenberg, Dimensionering af radiatorer til lavtemperatursystemer [Dimensioning of radiators for low temperature systems], HVAC. 48 (2012) 46-53.

[14] Danish Energy Agency, Håndbog for energikonsulenter. Enfamiliehuse. Beregnet forbrug - 2012 [Handbook for energy consultants. Single-family houses. Calculated consumption - 2012], 2012.

[15] S. Aggerholm, K. Grau, Bygningers energibehov - PC-program og beregningsvejledning [Energy demand of buildings - PC-program and calculation guide] - SBi-anvisning 213, Danish Building Research Institute, 2005.

[16] B. Bøhm, F. Schrøder, N.C. Bergsøe, Varmt Brugsvand - måling af forbrug og varmetab fra cirkulationsledninger [Domestic hot water - measurements of consumption and heat loss from circulation pipes] - SBi 2009:10, 2009.

[17] International Energy Agency, Retrofit Simulation Report - IEA ECBCS Annex 50 - Prefabricated systems for low energy renovation of residential buildings, 2011. http://www.emparen.ch/A50.htm.

[18] EQUA, Validation reports, (2015). http://www.equaonline.com/iceuser/new_validationreports.html (accessed June 9, 2015).

[19] Equa Simulation, User Manual IDA Indoor Climate and Energy, 2013.

[20] Danish Standard - CEN/TC 130, DS/EN 442-2 - Radiators and convectors - Part 2: Test methods and rating, 2014.

[21] R. Thiemke, Effekt af for $\varnothing$ gelse af radiatorkapacitet [Effect of increased nominal radiator heating power], Dansk Gasteknisk Center, Hørsholm, Denmark, 1998.

[22] Danish Energy Agency, Bygningsreglementet 1995 - Erhvervs- og etagebyggeri [The Danish Building Code 1995 - Commercial and multi-storey buildings], (2015).

http://bygningsreglementet.dk/tidligerebygreg/0/40. 